NBS Special

Publication 480-40

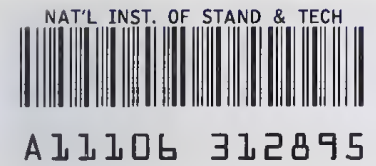

NBS

PUBLICATIONS

\title{
Paint Solubility Testing
}

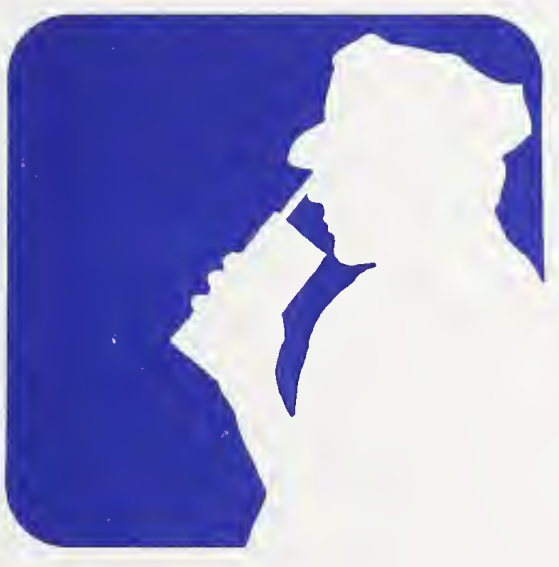

Law Enforcement

Technology

\section{U.S. DEPARTMENT OF COMMERCE National Bureau of Standards}

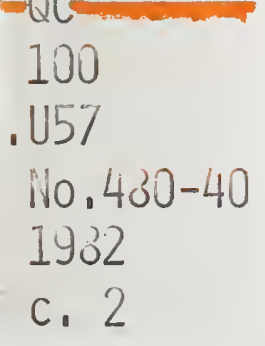


The Technology Assessment Program is sponsored by the Office of Development, Testing, and Dissemination of the National Institute of Justice (NIJ), U.S. Department of Justice. The program responds to the mandate of the Justice System Improvement Act of 1979, which created NIJ and directed it to encourage research and development to improve the criminal justice system and to disseminate the results to Federal, State, and local agencies.

The Technology Assessment Program is an applied research effort that determines the technological needs of justice system agencies, sets minimum performance standards for specific devices, tests commercially available equipment against those standards, and disseminates the standards and the test results to criminal justice agencies nationwide and internationally.

The program operates through:

The Technology Assessment Program Advisory Council (TAPAC) consisting of nationally recognized criminal justice practitioners from Federal, State, and local agencies, which assesses technological needs and sets priorities for research programs and items to be evaluated and tested.

The Law Enforcement Standards Laboratory (LESL) at the National Bureau of Standards, which develops voluntary national performance standards for compliance testing to ensure that individual items of equipment are suitable for use by criminal justice agencies. The standards are based upon laboratory testing and evaluation of representative samples of each item of equipment to determine the key attributes, develop test methods, and establish minimum performance requirements for each essential attribute. In addition to the highly technical standards, LESL also produces user guides that explain in non-technical terms the capabilities of available equipment.

The Technology Assessment Program Information Center (TAPIC) operated by the International Association of Chiefs of Police (IACP), which supervises a national compliance testing program conducted by independent agencies. The standards developed by LESL serve as performance benchmarks against which commercial equipment is measured. The facilities, personnel, and testing capabilities of the independent laboratories are evaluated by LESL prior to testing each item of equipment, and LESL helps the lnformation Center staff review and analyze data. Test results are published in Consumer Product Reports designed to help justice system procurement officials make informed purchasing decisions.

All publications issued by the National Institute of Justice, including those of the Technology Assessment Program, are available from the National Criminal Justice Reference Service (NCJRS), which serves as a central information and reference source for the Nation's criminal justice community. For further information, or to register with NCJRS, write to the National Institute of Justice, National Criminal Justice Reference Service, Washington, DC 20531.

Paul Cascarano, Assistant Director

National Institute of Justice

\section{ACKNOWLEDGMENTS}

\footnotetext{
This report was prepared by the Law Enforcement Standards Laboratory of the National Bureau of Standards under the direction of Paul H. Krupenie and Lawrence K. Eliason, Chief of LESL. The preparation of this report was sponsored by the National Institute of Justice, Lester D. Shubin, Standards Program Manager.
} 
by

John I. Thornton

Shmuel Kraus

Bruce Lerner

Beth Hendrickson

Forensic Science Group

Department of Biomedical and Environmental

Health Sciences

School of Public Health

University of California

Berkeley, CA 94720

and the

Law Enforcement Standards Laboratory

National Engineering Laboratory

National Bureau of Standards

Washington, DC 20234

prepared for the

National Institute of Justice

U.S. Department of Justice

Washington, DC 20531
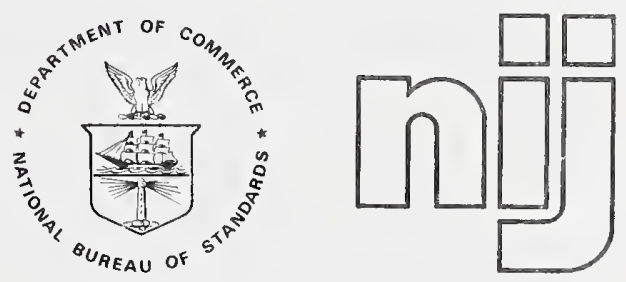

Issued

January 1982

\section{U.S. DEPARTMENT OF COMMERCE \\ Malcolm Baldrige, Secretary}

NATIONAL BUREAU OF STANDARDS

Ernest Ambler, Director 
Pavbret2 to vesus wroitsh

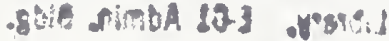

\section{seft that}

Library of Congress Catalog Card Number: 81-600176

National Bureau of Standards

Special Publication 480-40

Nat. Bur. Stand. (U.S.), Spec. Publ. 480-40, 20 pages

CODEN: XNBSAV

U.S. GOVERNMENT PRINTING OFFICE WASHINGTON: 1982

Available from the National Technical Information Service, Springfield, VA 22161. 


\section{FOREWORD}

The Law Enforcement Standards Laboratory (LESL) of the National Bureau of Standards (NBS) furnishes technical support to the National Institute of Justice (NIJ) program to strengthen law enforcement and criminal justice in the United States. LESL's function is to conduct research that will assist law enforcement and criminal justice agencies in the selection and procurement of quality equipment.

LESL is: (1) Subjecting existing equipment to laboratory testing and evaluation and (2) conducting research leading to the development of several series of documents, including national voluntary equipment standards, user guides, and technical reports.

- This document is a law enforcement technology report developed by LESL under the sponsorship of NIJ as part of the Technology Assessment Program, which is described on the inside front cover of this report. Additional reports as well as other documents are being issued under the LESL program in the areas of protective equipment, communications equipment, security systems, weapons, emergency equipment, investigative aids, vehicles, and clothing.

Technical comments and suggestions concerning this report are invited from all interested parties. They may be addressed to the Law Enforcement Standards Laboratory, National Bureau of Standards, Washington, DC 20234.

Lawrence K. Eliason, Chief Law Enforcement Standards Laboratory 


\section{CONTENTS}

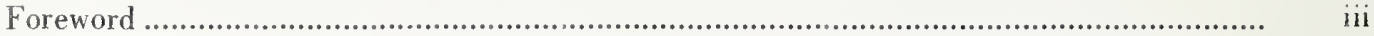

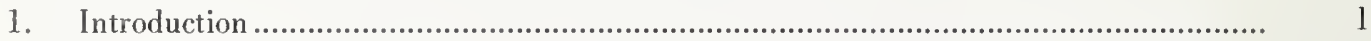

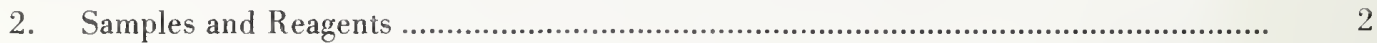

A. Sample Sources and Preparation ............................................................... 2

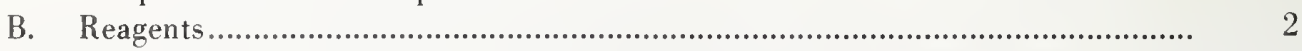

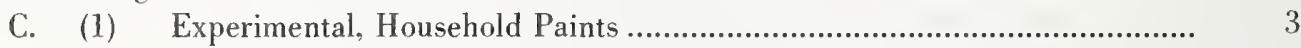

(2) Experimental, Automotive Paints ............................................................

3. Results and Discussion ...................................................................................

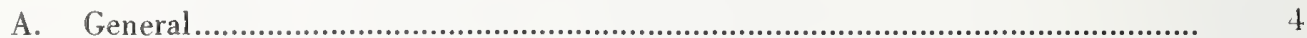

B. Household Paints-General Solubility ........................................................ 5

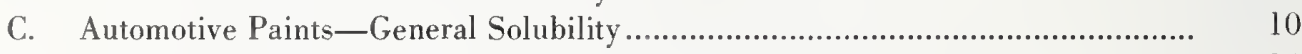

D. Automotive Paints—Sequential Solubility Scheme......................................... 14

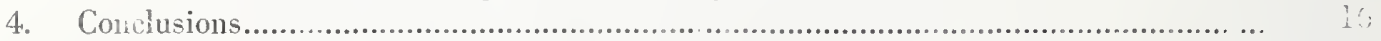




\title{
PAINT SOLUBILITY TESTING
}

\author{
John I. Thornton, Shmuel Kraus, Bruce Lerner, and Beth Hendrickson* \\ University of California, Berkeley, CA 94720
}

\begin{abstract}
This report presents the results of a study to develop criteria for the characterization of paint through solubility testing. Experiments were conducted with common solvents to classify chemical reactivity with automobile and household paints. Seven categories of reactivity are defined, which form the basis for specifying the extent of solubility of paints in various reagents under controlled conditions of time and temperature. The report also describes a novel solubility test procedure by which acrylic lacquers, organic-dispersed enamels, and water-based enamels can be distinguished through sequential testing, a characterization not previously accomplished with solubility testing.
\end{abstract}

Key words: automotive paints; household paints; sequential tests; solubility tests.

\section{INTRODUCTION}

The Nationwide Crime Laboratory Proficiency Testing Project conducted by the Law Enforcement Assistance Administration and the Forensic Sciences Foundation demonstrated a need for standardization in paint solubility testing for forensic purposes. ${ }^{1}$ Based on results obtained for tests of several paint samples distributed to crime laboratories throughout the country, it was apparent that there was little or no standardization in the solubility test methods used, reproducibility of test results, and criteria for the evaluation and reporting of results, or, for that matter, in the rationale behind the use of a particular array of solvents. For example, one laboratory would report that a given paint sample was soluble in sulfuric acid, while another laboratory would report that the paint was insoluble in this reagent. Reagent concentrations and times of reaction were frequently not reported. It was apparent that there was large variation in the reagents used, in the time allowed for the reagent to act on the paint, in the temperature at which the tests were conducted, and in the criteria applied to the term "soluble."

The purpose of the present study was to develop criteria to apply to solubility testing and chemical reactivity of automotive paints, and to standardize reagent concentration and other parameters. The principal focus of the study was testing acrylic enamels used as automotive finishes, since prior to this study these paints were reported to be virtually unreactive to all solvents when subjected to solubility tests. An ancillary objective was to apply these criteria of solubility and reactivity to testing household paints.

\footnotetext{
* Forensic Science Group, Department of Biomedical and Environmental Health Sciences, School of Public Health.

' Crime Laboratory Proficiency Testing Research Program. Joseph L. Peterson, Ellen L. Fabricant, Kenneth S. Field, and John I. Thornton. Law Enforcement Assistance Administration, U.S. Government Printing Office, Washington. DC. Oct. 1978, $287 \mathrm{pp}$.
} 


\section{A. Sample Sources and Preparation}

Samples of vinyl, alkyd, acrylic, and epoxy paints were obtained from retail distributors in Virginia, because State law requires all components of a paint to be indicated on the label, facilitating a confirmation of the generic type of paint. The samples tested were specifically designated as exterior grade paint. The vinyl and acrylic paints were water-based and the alkyd and epoxy paints were oil-based. The epoxy was cross-linked. The paints were selected to be deeply pigmented, i.e., highly saturated with pigment, to permit a more critical assessment of solubility and/or pigment leach. Linseed oil paint, as an example of an air-oxidizing drying oil paint, is rarely marketed now; the linseed oil paint used in this study was made by adding pigment ( $25 \%$ by weight of rutile titanium dioxide) to commercially available dark boiled linseed oil by stirring. No thinners were used; but dark boiled linseed oil contains a drier. The household paints were brushed as thin [approximately $3 \mathrm{mil}(.075 \mathrm{~mm}$ )] films onto a sheet acetate substrate and permitted to fully cure at room temperature for a minimum of 5 weeks before testing. No primers were used with any of the household paints.

The automobile paints tested were the separate chemical samples from the 1977 National Bureau of Standards' "Reference Collection of Automotive Paints." These automotive paints consisted of acrylic lacquers and acrylic enamels as defined by Williams. ${ }^{3}$ Acrylic enamels were of three types: (1) organic dispersed enamels, also referred to as "solvent-thinned" enamels, (2) nonaqueous dispersion enamels, and (3) water-based enamels. The term water-based enamel is used interchangeably with water dispersion enamel or aqueous dispersion enamel.

\section{B. Reagents}

A wide range of solvents and chemical reagents were tested for their efficacy in dissolving both household and automotive paints. These included acids, bases, and organic solvents covering a wide range of polarity. Particular attention was given to reagents reported in the Crime Laboratory Proficiency Project report as having applicability to paint solubility testing.

All chemicals were of analytical reagent grade. Dilutions, whether of a liquid stock solution or of a stock solid, are expressed as a weight to weight $(\mathrm{w} / \mathrm{w})$ percentage.

\section{Stock Acids:}

Acetic Acid, $\mathrm{CH}_{3} \mathrm{COOH}$, glacial (17.4 M)

Hydrochloric Acid, $\mathrm{HCl}$, conc. (11.6 M)

Nitric Acid, $\mathrm{HNO}_{3}$, conc. (15.4 M)

Phosphoric Acid, $\mathrm{H}_{3} \mathrm{PO}_{4}$, conc. (14.6 M)

Sulfuric Acid, $\mathrm{H}_{2} \mathrm{SO}_{4}$, conc. (18.0 M)

\section{Stock Bases:}

Ammonium Hydroxide, $\mathrm{NH}_{4} \mathrm{OH}$, conc. (14.8 M)

Potassium Hydroxide, $\mathrm{KOH}, 95$ percent sticks

Sodium Hydroxide, $\mathrm{NaOH}, 95$ percent sticks

\footnotetext{
${ }^{2} 1977$ Reference Collection of Automotive Paints, National Bureau of Standards and Manufacturers Council on Color and Appearance, lnc.

"Automotive Finishes. Ralph A. Williams, Federation Series on Coatings Technology, Federation of Societies for Paint Technology, 121 South Broad St., Philadelphia, PA 19107, 1977, 36 pp.
} 
Organic Solvents:

Acetone, b.p. $56^{\circ} \mathrm{C}$

Amyl Acetate, b.p. $149^{\circ}$

Benzene, b.p. $80^{\circ}$

$t$-Butanol, b.p. $82^{\circ}$

Carbon Disulfide, b.p. $46^{\circ}$

Carbon Tetrachloride, b.p. $76^{\circ}$

Chloroform, b.p. $61^{\circ}$

Dichloroethane, b.p. $57^{\circ}$

Dichloromethane, b.p. $40^{\circ}$

Dimethylformamide (DMF), b.p. 149-156

Dimethylsulfoxide (DMSO), b.p. $189^{\circ}$

$p$-Dioxane, b.p. $101^{\circ}$

Ethanol, absolute, b.p. $78^{\circ}$

Ethyl Acetate, b.p. $77^{\circ}$

Methanol, absolute, b.p. $65^{\circ}$

Petroleum Ether, b.p. $60-80^{\circ}$

Piperidine, b.p. $106^{\circ}$

Tetrahydrofuran (THF), b.p. $64^{\circ}$

Toluene, b.p. $110^{\circ}$

Xylene (o-, $m$-, and $p$-isomers), b.p. $135-140^{\circ}$

\section{C.(1) Experimenfal, Household Paints}

The effect of each solvent on each sample of paint was evaluated at room temperature $\left(23^{\circ} \mathrm{C}\right)$ and, for most solvents, at elevated temperatures. The high volatility of certain solvents (e.g., carbon disulfide and acetone) presented serious practical difficulties in solubility testing at elevated temperatures. Refluxing would have addressed this problem, but it was concluded that this would not be practical for routine use in forensic laboratories and that standardization of refluxing procedures would create further problems.

Tests at all temperatures were observed under a low-power stereoscopic binocular microscope. Tests at room temperature were conducted in a white porcelain spot tile. The tests at elevated temperature were conducted in tubes immersed in a water bath heated to a temperature determined by the boiling point of the reagent. The temperature selected was close to the boiling point, but not so close that the vapor pressure at the selected temperature would result in an excessively rapid evaporation of the solvent. The tubes and reagents were preconditioned to the temperature of the water bath prior to the addition of the paint samples.

At all temperatures, the ratio of reagent to sample was greater than $50: 1$ by weight. Samples of paint approximately $1 \mathrm{~mm} \times 1 \mathrm{~mm}$ were removed from their acetate substrate and immersed in the reagent for a period of $5 \mathrm{~min}$. The reagents containing the samples were stirred at intervals of 1 min. Various reaction times were tried, but the 5 -min reaction time was the most suitable: exposure times up to several hours did not alter the chemical reactivity assessed at $5 \mathrm{~min}$. Solubility or other chemical reactivity was assessed by the following criteria:

Soluble A sample was determined to be soluble if the paint was completely disintegrated within $5 \mathrm{~min}$, either as a result of solvation or chemical decomposition.

Partially soluble A sample was determined to be partially soluble if after $5 \mathrm{~min}$ a significant amount of pigment (more than half) was leached from the paint with some, although incomplete, disintegration of the vehicle.

Pigment leach A sample was determined to have undergone pigment leach if the paint remained substantially intact after $5 \mathrm{~min}$, but with some pigment (less than half) extracted by the reagent. Pigment leach is distinguished from "partially soluble" in that the paint remains substantially intact and exhibits little or no visual evidence of disintegration of the vehicle. 
Swell A sample was said to swell if there was a significant and uniform expansion of the paint, but with no noticeable solubility or pigment leach.

Curl A sample was said to curl if there was a tendency for the paint to curl in the reagent, but with no noticeable solubility or pigment leach. Curling is probably an asymmetrical form of swelling.

Discolor A sample was said to discolor if the paint turned brown or black. This phenomenon was noted with the mineral acids, and represents a charring of the organic matter. Care must be exercised when dealing with black or brown paints that true solvation not be confused with discoloration; although arising from different chemical considerations, the subjective appearances would be quite similar.

Soften A sample was said to soften if, after exposure to the solvent, the paint fragment could be penetrated with a needle but was otherwise not visibly affected.

\section{C.(2) Experimental, Automotive Paints}

In the case of the sequential solvent testing of automotive paints, the tests were conducted in a white porcelain spot tile. Heating, where needed, was with a $500-\mathrm{W}$ infrared lamp $15 \mathrm{~cm}$ from the tile. Tests were observed under a low-power stereoscopic binocular microscope. Paint samples approximately $1 \mathrm{~mm} \times 1 \mathrm{~mm}$ were removed from their metal substrate and placed in the spot plate. Glacial acetic acid at room temperature was added. If the paint was an acrylic lacquer, it would dissolve within $2 \mathrm{~min}$. If the paint did not dissolve, the spot plate was heated with the infrared lamp. When the temperature was within $10^{\circ} \mathrm{C}$ of the boiling point of glacial acetic acid $\left(117^{\circ} \mathrm{C}\right)$, the paint would dissolve within $2 \mathrm{~min}$ if the paint were an organic-dispersed enamel.

At a distance of $15 \mathrm{~cm}$ from the $500-\mathrm{W}$ lamp a steady state situation was achieved with respect to temperature; the heat input was equal to the heat loss, and the temperature remained essentially constant at approximately $107-110^{\circ} \mathrm{C}$. If no reaction occurred under heating, the acetic acid was removed by means of a pipette, a few drops of concentrated $\mathrm{HNO}_{3}$ was added, and the sample was reheated with the infrared lamp for an additional $3 \mathrm{~min}$. The paint sample was then washed in distilled water and dried. This was accomplished in situ by drawing off the acid with a pipette, adding water, drawing off the water with a pipette, repeating the washing step, and drying the sample by heat from the infrared lamp. A saturated solution of potassium hydroxide in tertiary butanol was then added, and the solution was heated by means of the infrared lamp. The waterbased enamels then dissolved.

\section{RESULTS AND DISCUSSION}

\section{A. General}

Both household and automotive paints vary within a particular generic type. This variation in composition (e.g., the substitution of a methoxy group into a resin monomer) results in some variation in solubility behavior. For example, within the acrylic enamel group, hot nitric acid will only discolor one paint sample, but will completely dissolve other samples. As a consequence, the use of solubility testing to individualize a paint or to definitively characterize an evidence paint as belonging to a particular generic type should be attempted only with caution. The principal application of paint solubility testing is in screening or comparison.

Certain generalizations, however, may be made. For household paints, the most effective solvents are concentrated $\mathrm{H}_{2} \mathrm{SO}_{4}, 30$ percent (w/w) KOH, and hot $\mathrm{HCl}$. These reagents will result in either a dissolution of the paint or in a color reaction which may have some diagnostic value. 
For automotive paints, acetone, phosphoric acid, and dimethylformamide are well suited lo dissolve the acrylic lacquers. The acrylic enamels are much more resistant to the effects of solvents in general, but the strong mineral acids may achieve some reactivity. The failure of the acrylis: enamels to dissolve in most common reagents led to the sequential testing which was the princi pal thrust of this study. Because of their significance the findings will be discussed in a separate section.

\section{B. Household Paints-General Solubility}

The results of the solubility testing of the household paints at room temperature and at elevated temperatures are in tables $1 \mathrm{~A}$ through $1 \mathrm{E}, 2 \mathrm{~A}$ through $2 \mathrm{E}$, and 7. Non-polar solvents|have very little effect in dissolving household paints. If a solvent had littie or no effect on any paint at any temperature up to and including the boiling temperature, it will not appear in any of the tabular data except to indicate the comprehensiveness of the testing conducted, i.e., to indicate the logical candidate solvents within a particular group.

TAlst: 1A. Houschold paints at room temperature', concentrated acids

\begin{tabular}{|c|c|c|c|c|}
\hline \multirow[b]{2}{*}{ Paint } & \multicolumn{4}{|c|}{ Acid } \\
\hline & $\begin{array}{l}\mathrm{H}_{2} \mathrm{SO}_{4} \\
\text { (conc.) }\end{array}$ & $\begin{array}{c}\mathrm{HCl} \\
\text { (conc.) }\end{array}$ & $\begin{array}{l}\mathrm{HNO}_{3} \\
\text { (conc.) }\end{array}$ & $\begin{array}{c}\mathrm{HAc} \\
\text { (glacial) }\end{array}$ \\
\hline Vinyls & Soluble & No reaction & Softens; may discolor & Softens \\
\hline Alkyds & Curls; may discolor & No reaction & Curls; may discolor & Curls \\
\hline Acrylics & Soluble & No reaction & Softens & Softens \\
\hline Linseed oil base & Soluble; may discolor & No reaction & Discolors & No reaction \\
\hline
\end{tabular}

TA1B1: 1B. Household paints at room temperature, strong bases

\begin{tabular}{llllll}
\hline & & \multicolumn{3}{c}{ Base } \\
\cline { 2 - 5 } \multicolumn{1}{c}{ Paint } & $\begin{array}{c}\mathrm{NaOH} \\
(30 \%, w / w)\end{array}$ & $\begin{array}{c}\mathrm{KOH} \\
(30 \%, w / w)\end{array}$ & $\begin{array}{c}\mathrm{NH}_{4} \mathrm{OH} \\
(\mathrm{conc})\end{array}$ & $\begin{array}{c}\mathrm{KOH} \\
(1 \%, w / w)\end{array}$ & $\begin{array}{c}\mathrm{NaOH} \\
(50 \%, w / w)\end{array}$ \\
\hline Vinyls & No reaction & No reaction & No reaction & No reaction & No reaction \\
Alkyds & No reaction & Soluble & Curls; may discolor & No reaction & No reaction \\
Acrylics & No reaction & No reaction & No reaction & No reaction & No reaction \\
Linseed oil base & Soluble & Soluble & No reaction & Softens & No reaction \\
\hline
\end{tabular}


TAB1.: IC. Household paints at room temperature, non-polar solvents

\begin{tabular}{|c|c|c|c|c|c|}
\hline \multirow[b]{2}{*}{ Paint } & \multicolumn{5}{|c|}{ Solvent } \\
\hline & $\mathrm{C}_{6} \mathrm{H}_{6}$ & $\mathrm{CS}_{2}$ & $\mathrm{CCl}_{4}$ & Dioxane & $\begin{array}{l}\text { Pet. } \\
\text { Ether }\end{array}$ \\
\hline Vinyls & No reaction & No reaction & No reaction & No reaction & No reaction \\
\hline Alkyds & No reaction & No reaction & No reaction & $\begin{array}{l}\text { No reaction, } \\
\text { or may soften }\end{array}$ & No reaction \\
\hline Acrylics & Softens & No reaction & Softens & Softens & No reaction \\
\hline Linseed oil base & No reaction & No reaction & No reaction & Softens & Swells \\
\hline
\end{tabular}

TABt.: ID. Household paints at room temperature. low to medium polarity (dielectric constant (6) solvents

\begin{tabular}{|c|c|c|c|c|}
\hline \multirow[b]{2}{*}{ Paint } & \multicolumn{4}{|c|}{ Solvent } \\
\hline & Toluene & Xylene & $\begin{array}{r}\text { Amyl } \\
\text { acetate }\end{array}$ & $\mathrm{CHCl}_{3}$ \\
\hline Vinyls & No reaction & Softens & Softens & Softens \\
\hline Alkyds & No reaction & No reaction & Softens & No reaction \\
\hline Acrylics & Softens & Softens & Softens & Softens \\
\hline Linseed oil base & No reaction & No reaction & Softens & No reaction \\
\hline
\end{tabular}




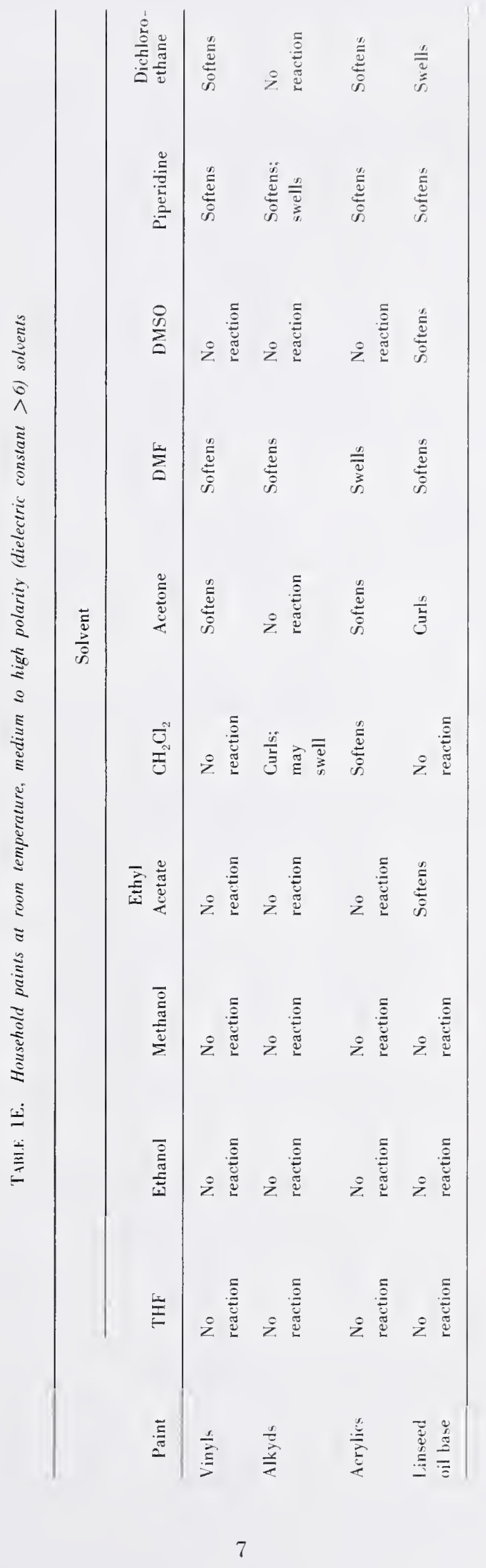


TABI.t, 2A. Household paints at $80 \pm 5{ }^{\circ} \mathrm{C}$, concentrutud aculs

\begin{tabular}{|c|c|c|c|c|}
\hline \multirow[b]{2}{*}{ Paint } & \multicolumn{4}{|c|}{ Acid } \\
\hline & $\begin{array}{l}\mathrm{H}_{2} \mathrm{SO}_{4} \\
\text { (conc.) }\end{array}$ & $\begin{array}{c}\mathrm{HCl} \\
\text { (conc.) }\end{array}$ & $\begin{array}{c}\mathrm{HNO}_{3} \\
\text { (conc.) }\end{array}$ & $\begin{array}{c}\text { HAc } \\
\text { (glacial) }\end{array}$ \\
\hline Vinyls & Soluble & Discolors & $\begin{array}{l}\text { Softens; } \\
\text { pigment leach }\end{array}$ & Softens \\
\hline Alkyds & Soluble & No reaction & Discolors & No reaction \\
\hline Acrylics & Soluble & Soluble & Soluble & Softens \\
\hline Linseed oil base & Soluble; discolors & Discolors & Soluble; discolors & No reaction \\
\hline
\end{tabular}

TAвц: 2B. Household paints at elevated temperatures, strong bases

\begin{tabular}{llllc}
\hline & & & \multicolumn{3}{c}{ Base } \\
\cline { 2 - 5 } \multicolumn{1}{c}{ Paint } & $\begin{array}{c}30 \% \mathrm{NaOH} ; \\
80{ }^{\circ} \mathrm{C}\end{array}$ & $\begin{array}{c}30 \% \mathrm{KOH} ; \\
80{ }^{\circ} \mathrm{C}\end{array}$ & $\begin{array}{c}1 \% \mathrm{KOH} ; \\
9{ }^{\circ} \mathrm{C}\end{array}$ & $\begin{array}{c}50 \% \mathrm{NaOH} ; \\
9{ }^{\circ} \mathrm{C}\end{array}$ \\
\hline Vinyls & No reaction & No reaction & No reaction & No reaction \\
Alkyds & Discolors & Soluble & Soluble & Discolors \\
Acrylics & No reaction & No reaction & No reaction & No reaction \\
Linseed oil base & Soluble & Discolors; partially soluble & Discolors & No reaction \\
\hline
\end{tabular}

TAB1.E 2C. Household paints at elevated temperatures, non-polar solvents

\begin{tabular}{llll}
\hline & & \multicolumn{1}{c}{ Solvent } & \\
\cline { 2 - 4 } \multicolumn{1}{c}{ Paint } & $\mathrm{C}_{6} \mathrm{H}_{6}, 60{ }^{\circ} \mathrm{C}$ & $\mathrm{CCl}_{4}, 60{ }^{\circ} \mathrm{C}$ & Dioxane, $95{ }^{\circ} \mathrm{C}$ \\
\hline Vinyls & Softens & No reaction & Swells \\
Alkyds & No reaction & No reaction & Softens \\
Acrylics & Swells & Swells & Softens \\
Linseed oil base & No reaction & No reaction & No reaction \\
\hline
\end{tabular}

TABI.t. 2D. Household paints at elevated temperalures, low to medium polarity (dielectric constant <6) solvents

\begin{tabular}{|c|c|c|c|c|}
\hline \multirow[b]{2}{*}{ Paint } & \multicolumn{4}{|c|}{ Solvent } \\
\hline & $\begin{array}{c}\text { Toluene, } \\
80^{\circ} \mathrm{C}\end{array}$ & $\begin{array}{c}\text { Xylene, } \\
95^{\circ} \mathrm{C}\end{array}$ & $\begin{array}{c}\text { Amyl acetate } \\
95^{\circ} \mathrm{C}\end{array}$ & $\begin{array}{l}\mathrm{CHCl}_{3,}, \\
60^{\circ} \mathrm{C} .\end{array}$ \\
\hline Vinyls & No reaction & Pigment leach & Softens & Softens \\
\hline Alkyds & Softens: discolors & Softens & No reaction & No reaction \\
\hline Acrylics & Curls & Curls & Softens & Softens \\
\hline Linseed oil base & No reaction & No reaction & Curls & No reaction \\
\hline
\end{tabular}




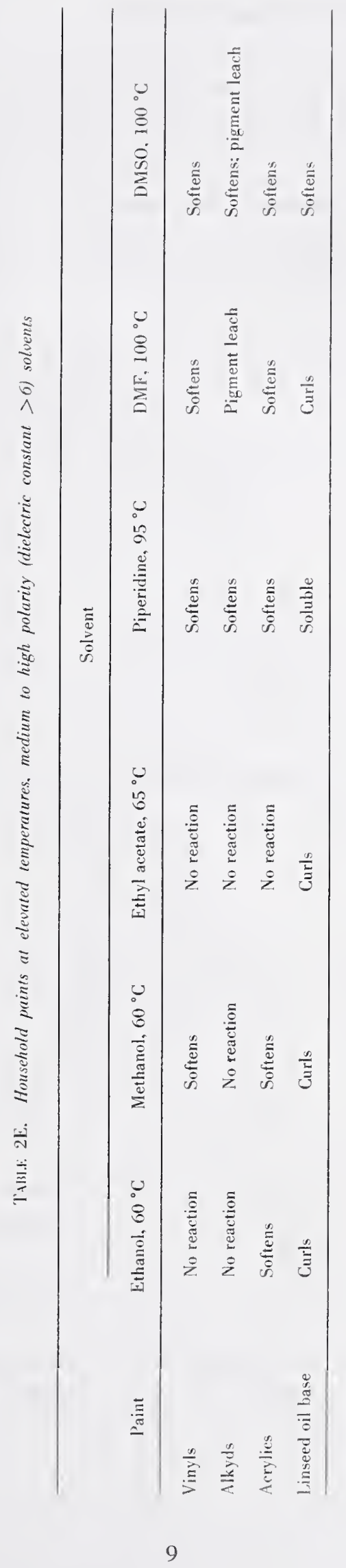




\section{Automotive Paints-General Solubility}

All acrylic lacquers dissolved in room-temperature glacial acetic acid. No acrylic enamel dissolved in this acid, even at high temperature. The results of solubility testing of acrylic lacquers at room temperature and at elevated temperatures are in tables $3 \mathrm{~A}$ through $4 \mathrm{~B}$. Historically, these paints have not presented any problem with solubility testing, and a number of solvents are quite efficient in dissolving these paints and distinguishing them from the acrylic enamels. The results of solubility testing of acrylic enamels at room temperature and at elevated temperatures are in tables 5A through table 6. The aqueous dispersion enamels are poorly represented in the NBS 1977 Reference Collection of Automotive Paints, owing to their recent introduction; the reactions of a single paint of this type are presented in table 6 .

T4131.t: 3A. Automotive paints: acrylic lacquers at room temperature, strong acids

\begin{tabular}{|c|c|c|c|c|}
\hline \multirow[b]{2}{*}{ Paint } & \multicolumn{4}{|c|}{ Solvent } \\
\hline & $\begin{array}{l}\mathrm{H}_{2} \mathrm{SO}_{4} \\
\text { (conc.) }\end{array}$ & $\begin{array}{l}\mathrm{H} \mathrm{NO}_{3} \\
\text { (conc.) }\end{array}$ & $\begin{array}{l}\mathrm{H}_{3} \mathrm{PO}_{4} \\
\text { (conc.) }\end{array}$ & $\begin{array}{c}\mathrm{HCl} \\
\text { (conc.) }\end{array}$ \\
\hline \multicolumn{5}{|c|}{ Acrylic solution lacquer } \\
\hline DA77G0333 & Soluble & Pigment leach & No reaction & No reaction \\
\hline NA77B0334 & $\begin{array}{l}\text { Partially } \\
\text { soluble }\end{array}$ & Partially soluble, discolors & No reaction & No reaction \\
\hline PA77L0335 & Soluble & No reaction & Discolors & Discolors \\
\hline \multicolumn{5}{|c|}{ Acrylic dispersion lacquer } \\
\hline DB77B0334 & $\begin{array}{l}\text { Partially } \\
\text { soluble }\end{array}$ & Partially soluble, discolors & Discolors & Discolors \\
\hline
\end{tabular}

TA131.F. 3B. Automotive paints: acrylic lacquers at $80^{\circ} \mathrm{C}$, strong acids

\begin{tabular}{|c|c|c|c|c|}
\hline \multirow[b]{2}{*}{ Paint } & \multicolumn{4}{|c|}{ Solvent } \\
\hline & $\begin{array}{l}\mathrm{H}_{2} \mathrm{SO}_{1} \\
\text { (conc.) }\end{array}$ & $\begin{array}{l}\mathrm{HNO}_{3} \\
\text { (conc.) }\end{array}$ & $\begin{array}{l}\mathrm{H}_{3} \mathrm{PO}_{4} \\
\text { (conc.) }\end{array}$ & $\begin{array}{c}\mathrm{HCl} \\
\text { (conc.) }\end{array}$ \\
\hline \multicolumn{5}{|c|}{ Acrylic solution lacquer } \\
\hline DA77G0333 & Soluble & Pigment leach & Discolors & Pigment leach \\
\hline NA77B0334. & Soluble & $\begin{array}{l}\text { Partially soluble, } \\
\text { discolors }\end{array}$ & Partially soluble & No reaction \\
\hline PA77L0335 & Soluble & Softens & Partially soluble & No reaction \\
\hline \multicolumn{5}{|c|}{ Acrylic dispersion lacquer } \\
\hline DB77B0334 & Soluble & $\begin{array}{l}\text { Partially soluble, } \\
\text { discolors }\end{array}$ & $\begin{array}{l}\text { Partially soluble, } \\
\text { discolors }\end{array}$ & Discolors \\
\hline
\end{tabular}




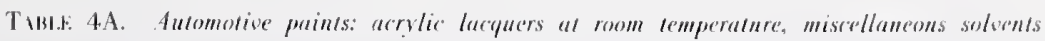

\begin{tabular}{|c|c|c|c|}
\hline \multirow[b]{2}{*}{ Paint } & \multicolumn{3}{|c|}{ Sölvenl } \\
\hline & Acelone & DMF & $30 \% \mathrm{Na}() \mathrm{H}(\mathrm{w} / \mathrm{w})$ \\
\hline \multicolumn{4}{|l|}{ Acrylic solution lacquer } \\
\hline DA77G0333 & Soluble & Soluble & No reartion \\
\hline NA77B0334 & Soluble & Soluble & No reaction \\
\hline PA77L0335 & Soluble & Soluble & No reaction \\
\hline \multicolumn{4}{|c|}{ Acrylic dispersion lacquer } \\
\hline БВ 7780334 & Soluble & Soluble & No reaction \\
\hline
\end{tabular}

TAII.F. 4B. Automotive paints: acrylic lacquers at elevated temperuture. miscellaneous solvents

\begin{tabular}{clc}
\hline & & Solvent \\
\hline Paint & $\mathrm{DMF}, 80^{\circ} \mathrm{C}$ & $30 \% \mathrm{NaOH}(\mathrm{w} / \mathrm{w}) .80{ }^{\circ} \mathrm{C}$ \\
\hline Acrylic solution lacquer & & No reaction \\
DA77G0333 & Soluble & No reaction \\
NA77B0334 & Soluble & No reaction \\
Acrylic dispersion lacquer & Soluble & \\
DB77B0334 & & No reaction \\
\hline
\end{tabular}


T+BIE. 5A. Automotive paints: acrylic enamels at room temperature. strong acids

\begin{tabular}{|c|c|c|c|c|}
\hline \multirow[b]{2}{*}{ Paint } & \multicolumn{4}{|c|}{ Solvent } \\
\hline & $\begin{array}{l}\mathrm{H}_{2} \mathrm{SO}_{4} \\
\text { (conc.) }\end{array}$ & $\begin{array}{l}\mathrm{HNO}_{3} \\
\text { (conc.) }\end{array}$ & $\begin{array}{l}\mathrm{H}_{3} \mathrm{PO}_{4} \\
\text { (conc.) }\end{array}$ & $\begin{array}{c}\mathrm{HCl} \\
\text { (conc.) }\end{array}$ \\
\hline \multicolumn{5}{|c|}{$\begin{array}{l}\text { Solvent-thinned (organic dispersed) } \\
\text { acrylic enamel }\end{array}$} \\
\hline DC77F0339 & Discolors & Pigment leach & Curls & $\begin{array}{l}\text { Pigment leach. } \\
\text { discolors }\end{array}$ \\
\hline FC77C0090 & Curls & Curls & No reaction & No reaction \\
\hline LC77E0235 & $\begin{array}{l}\text { Pigment leach. } \\
\text { discolors }\end{array}$ & $\begin{array}{l}\text { Pigment leach. } \\
\text { discolors }\end{array}$ & No reaction & No reaction \\
\hline NC77B0308 & No reaction & No reaction & No reaction & No reaction \\
\hline PC77J0255 & Discolors & Pigment leach & No reaction & Discolors \\
\hline \multicolumn{5}{|l|}{ Non-aqueous dispersion enamel } \\
\hline AN77H0313 & Discolors & No reaction & No reaction & No reaction \\
\hline $\mathrm{BN} 77 \mathrm{E} 0222$ & Discolors & Pigment leach & No reaction & No reaction \\
\hline CN77A0123 & Discolors & No reaction & No reaction & No reaction \\
\hline FN77E0222 & Discolors & $\begin{array}{l}\text { Pigment leach, } \\
\text { curls }\end{array}$ & No reaction & No reaction \\
\hline $\mathrm{KN} 77 \mathrm{C} 0090$ & No reaction & No reaction & No reaction & No reaction \\
\hline LN77B0149 & Discolors & No reaction & No reaction & No reaction \\
\hline NN77B0092 & Discolors & Discolors & Discolors & Discolors \\
\hline PN77F0314 & Discolors & Pigment leach & No reaction & Discolors \\
\hline
\end{tabular}


TAB1: 5B. Automotive paints: acrylic enamels at $80 \pm 5^{\circ} \mathrm{C}$, strong arids

\begin{tabular}{|c|c|c|c|c|}
\hline \multirow[b]{2}{*}{ Paint } & \multicolumn{4}{|c|}{ Solvent } \\
\hline & $\begin{array}{l}\mathrm{H}_{2} \mathrm{SO}_{4} \\
\text { (conc.) }\end{array}$ & $\begin{array}{l}\mathrm{HNO}_{3} \\
\text { (conc.) }\end{array}$ & $\begin{array}{r}\mathrm{H}_{3,} \mathrm{PO}_{4} \\
\text { (conc.) }\end{array}$ & $\begin{array}{c}\mathrm{HCl} \\
(\text { conc.) }\end{array}$ \\
\hline \multicolumn{5}{|c|}{$\begin{array}{l}\text { Solvent-thinned (organic dispersed) } \\
\text { acrylic enamel }\end{array}$} \\
\hline DC77F0339 & Discolors & Soluble & Curls & $\begin{array}{l}\text { Discolors, } \\
\text { pigment leach }\end{array}$ \\
\hline $\mathrm{FC} 77 \mathrm{C} 0090$ & Soluble & Soluble & No reaction & No reaction \\
\hline LC77E0235 & Discolors & Soluble & No reaction & No reaction \\
\hline NC77B0308 & Discolors & Discolors & Softens & Discolors \\
\hline PC77J0255 & Discolors & Soluble & Soluble & Discolors \\
\hline \multicolumn{5}{|l|}{ Non-aqueous dispersion enamel } \\
\hline AN77H0313 & Discolors & Partially soluble & Soluble & Discolors \\
\hline $\mathrm{BN} 77 \mathrm{E} 0222$ & Discolors & Partially soluble & No reaction & No reaction \\
\hline CN77A0123 & Soluble & Partially soluble & No reaction & No reaction \\
\hline FN77E0222 & Discolors & Partially soluble & No reaction & No reaction \\
\hline $\mathrm{KN} 77 \mathrm{C} 0090$ & Discolors & Soluble & No reaction & Softens \\
\hline LN77B0149 & Discolors & Soluble & No reaction & No reaction \\
\hline NN77B0092 & Discolors & Soluble & Partially soluble & Softens \\
\hline PN77F0314 & Discolors & Soluble & Soluble & Discolors \\
\hline
\end{tabular}


TA11.: 6. Aqueous dispersion enamel (NBS \#NW77E0054)-temperature as noted

\begin{tabular}{lll}
\hline & & \multicolumn{2}{c}{ Temperature } \\
\cline { 2 - 3 } Solvent & Room temperature & \multicolumn{1}{c}{$8{ }^{\circ} \mathrm{C}$} \\
\hline $\mathrm{H}_{2} \mathrm{SO}_{4}$ (conc.) & Curls, pigment leach & Solution yellows \\
$\mathrm{H} \mathrm{NO}_{3}$ (conc.) & Curls, pigment leach & Soluble \\
$\mathrm{H}_{3} \mathrm{PO}_{4}$ (conc.) & No reaction & Pigment leach \\
$\mathrm{HCl}($ conc.) & No reaction & Pigment leach \\
$\mathrm{NaOH}(30 \%)$ & No reaction & No reaction \\
$\mathrm{DMF}$ & No reaction & Solution turns green \\
Acetone* & No reaction & NA \\
\hline
\end{tabular}

${ }^{*}$ Room temperature only; B. P. of acetone is $56.5^{\circ} \mathrm{C}$.

TABS: 7. Epoxy paint-lemperature as noted

\begin{tabular}{lll} 
& & Temperature \\
\cline { 3 - 3 } Solvent & Room temperature & $80{ }^{\circ} \mathrm{C}$ \\
\hline $\mathrm{H}_{2} \mathrm{SO}_{4}($ conc.) & Softens, browns & Soluble \\
$\mathrm{HNO}_{3}$ (conc.) & No reaction & No reaction \\
$\mathrm{H}_{3} \mathrm{PO}_{4}$ (conc.) & No reaction & No reaction \\
$\mathrm{HCl}($ conc.) & No reaction & No reaction \\
$\mathrm{NaOH}(30 \%)$ & No reaction & No reaction \\
$\mathrm{DMF}$ & No reaction & No reaction \\
$\mathrm{Acetone}$ & No reaction & NA \\
\hline
\end{tabular}

*Room temperature only; B. P. of acetone is $56.5^{\circ} \mathrm{C}$.

\section{Automotive Paints-Sequential Solubility Scheme}

The study of solubility characteristics of household paints follows the usual use of an array of solvents to assess the responses, e.g., the degree of solubility encountered. Topcoats for automobiles, by contrast, in many instances, were found to require a sequential testing scheme. To better express the rationale for this scheme, background information is presented on the chemical bond types that are to be broken in solubilizing such paints. Automobiles manufactured in the United States in recent years have been finished with acrylic topcoats. ${ }^{4}$ The acrylic resins may be in either a straight-chain thermoplastic as in the acrylic lacquers, or in a cross-linked thermoset form as in the acrylic enamels.

\footnotetext{
Williams, op cit.
} 
The sequential solvent testing of automotive paints was deriver from a review of the chemistry of automotive enamels by one of the authors (SK). 'This suggested that first it would be necessary to break the structural cross-linkages, followed by use of a reagent which would cause further dissolution of the partially-degraded polymer.

Acrylic lacquers are utilized for approximately 50 percent of all the automobile topcoat production in the United States. The basic resin is comprised of methyl methacrylate, which is modified by other methacrylic or acrylic monomers. The acrylic lacquers are applied in one of two forms: (1) solvent-thinned lacquers ${ }^{5}$ and (2) non-aqueous dispersion (NAD) lacquers." The latter types have slightly higher molecular weight polymers which are modified to achieve partial solubility in aliphatic solvents. Both types are readily soluble in many organic solvents, and there is no difference between the two types in the solubility characteristics of the paints after drying.

The acrylic enamels utilized as topcoats for automobiles are of three types: (1) solventthinned enamels, also referred to as organic dispersed enamels, (2) non-aqueous dispersions, and (3) water-based enamels. ${ }^{7}$ All three types are modified acrylic resins containing acrylic and methacrylic acids as well as hydroxy-containing monomers. The carboxyl and hydroxyl groups provide reactive sites for the crosslinking between polymer chains. The cross-linking agent most commonly used is butylated melamine formaldehyde.

The water-based acrylic enamels are based on polymers similar to those used in the organic dispersed enamels, except that the percentage of hydroxy-containing monomers is reduced and the percentage of the free acids is increased. The cross-linking agent for these enamels is hexamethoxy-methyl melamine. The water-based enamels, at the present time, represent a small portion of the total amount of acrylic enamels used in automotive applications. Their use has been stimulated by antipollution regulations, however, particularly on the West Coast, and their use is likely to increase in the future.

The types of chemical bonding involved in the cross-linked acrylic enamels are numerous. The principal types of bonds include:

1) Ester linkages between the methylol group of the melamine and the free acid in the acrylic chain, and the ester linkage of the hydroxy-alcohol in the acrylate.

2) Ether linkages between the methylol group of the melamine and the free hydroxy groups incorporated into the acrylic polymer.

3) Alkylamine-type linkages between the melamine and the methylol groups.

Each of these represents candidate linkages to be chemically attacked and broken in order to solubilize the otherwise insoluble polymer. The most sensitive bond to chemical attack is the ester bond. Bonds of this type are susceptible to hydrolytic attack by strong base, e.g., ethanolic $\mathrm{KOH}$. The alkylamine linkages may be broken by Hoffmann degradation. This degradation is carried out by exhaustive methylation of the amine with methyl iodide, oxidation of the product with hydrogen peroxide, followed by pyrolysis of the product. Because of the complexities of this latter approach, the former approach was first attempted. With a slight modification (substitution of tertiary-butanol), this method was applied successfully.

Saturated ethanolic $\mathrm{KOH}$ in the temperature range of $80-100{ }^{\circ} \mathrm{C}$ was found to be suitable for hydrolyzing the ester bonds. However, the solution must be freshly prepared or the results are not entirely reproducible. A saturated solution of $\mathrm{KOH}$ in tertiary-butanol was found to be a more suitable reagent for the enamels; this reagent need not be freshly prepared.

The water-based enamels are not dissolved by hot alcoholic $\mathrm{KOH}$ unless they are first treated with a strong acid. A pretreatment with hot conc. nitric acid chemically modifies the polymer to the extent that it becomes soluble in hot alcoholic $\mathrm{KOH}$.

\footnotetext{
${ }^{5}$ Solvent-thinned lacquers are also referred to as acrylic solution or organic dispersed lacquers

${ }^{6} \mathrm{NAD}$ lacquers are also referred to as acrylic dispersion lacquers.

Williams, op cit.
} 
Prior to this study, attempts to use solvents to characterize paint consisted of one-step tests, i.e., if a solvent failed to dissolve or react with a paint sample, it was discarded and another reagent was tried. This approach is sufficient to characterize the solubility reaction of reagents with household paints. The use of one reagent as an activator, with another solvent used in tanden on the same sample, is a novel approach. The present work describes a method wherein acrylic lacquers, organic-dispersed enamels, and water-based enamels can be distinguished by sequential tests. The method is outlined in figure 1. Primers do not interfere with this procedure. This represents a substantial breakthrough in the use of solubility testing for the characterization of automotive paints.

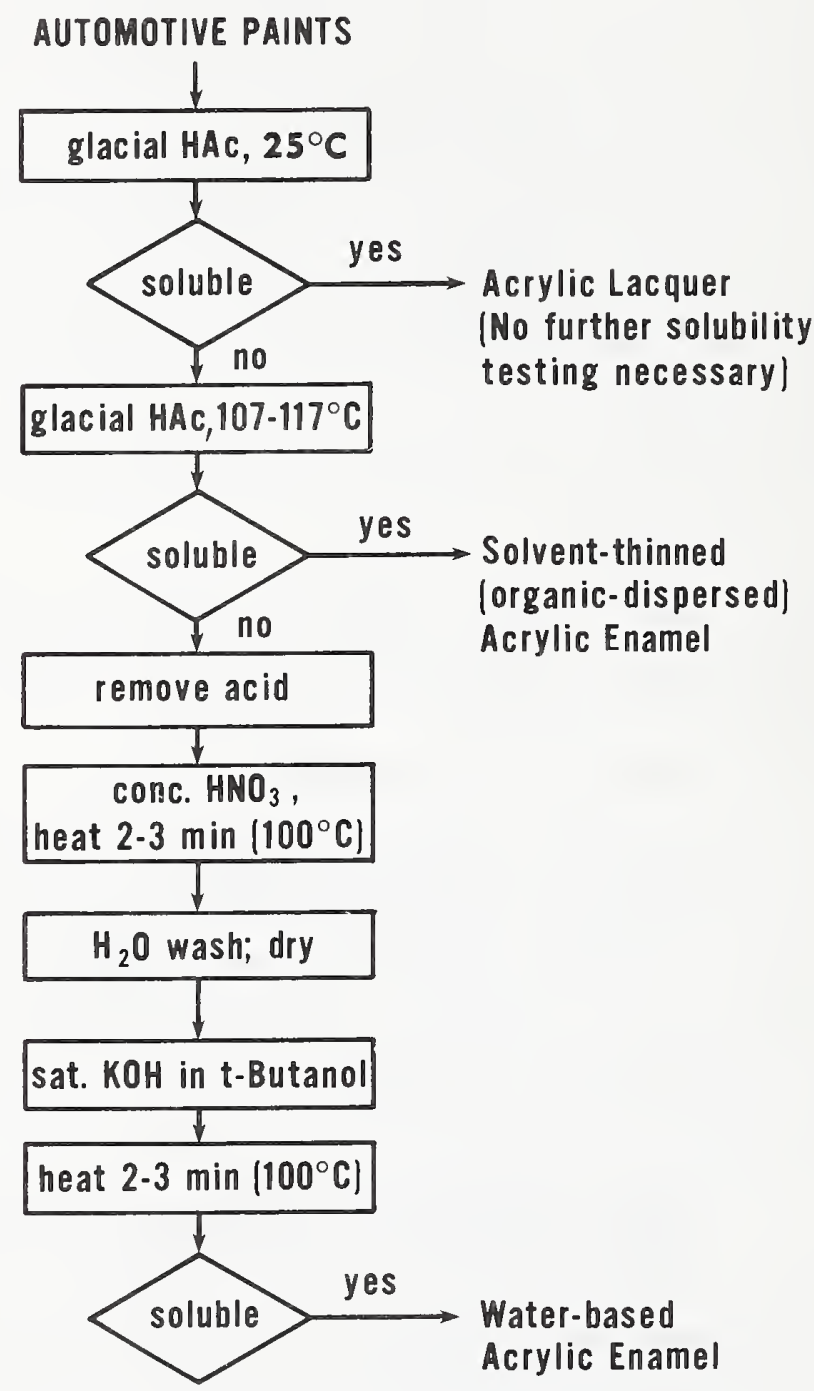

Fuit Rr. 1. Solubility scheme for automorive paints. 



\section{ANNOUNCEMENT OF NEW PUBLICATIONS ON NATIONAL CRIME AND RELATRD SUBJECTS}

Superintendent of Documents, Government Printing Office,

Washington, D.C. 20402

Dear Sir:

Please add my name to the announcement list of new publications to be issued on the above subjects (including this NBS series):

Name

Company

Address

City State Zip Code

(Notification Key N-538) 




\section{NBS TECHNICAL PUBLICATIONS}

\section{PERIODICALS}

JOURNAL OF RESEARCH-The Journal of Research of the National Bureau of Standards reports NBS research and development in those disciplines of the physical and engineering sciences in which the Bureau is active. These include physics, chemistry, engineering, mathematics, and computer sciences. Papers cover a broad range of subjects, with major emphasis on measurement methodology and the basic technology underlying standardization. Also included from time to time are survey articles on topics closely related to the Bureau's technical and scientific programs. As a special service to subscribers each issue contains complete citations to all recent Bureau publications in both NBS and nonABS medial. lssued sis times a year. Annual subseription: domente SIX: foregn $\$ 22.50$. Sungle copy $\$ 4.25$ domesta: $\$ 5.35$ loreign.

NOTE: The Journal was formerly published in two sections: Section A "Physics and Chemistry" and Section B "Mathematical Sciences."

DIMENSIONS/NBS-This monthly magazine is published to inform scientists, engineers, business and industry leaders, teachers, students, and consumers of the latest advances in science and technology, with primary emphasis on work at NBS. The magazine highlights and reviews such issues as energy research, fire protection, building technology, metric conversion, pollution abatement, health and safety, and consumer product performance. In addition, it reports the results of Bureau programs in measurement standards and techniques, properties of matter and materials, engineering standards and services, instrumentation, and automatic data processing. Annual subscription: domestic \$11; foreign $\$ 13.75$.

\section{NONPERIODICALS}

Monographs-Major contributions to the technical literature on various subjects related to the Bureau's scientific and technical activities.

Handbooks-Recommended codes of engineering and industrial practice (including safety codes) developed in cosperation with interested industries, professional organizations, and regulatory bodies.

Special Publications-Include proceedings of conferences sponsored by NBS, NBS annual reports, and other special publications appropriate to this grouping such as wall charts, pocket cards, and bibliographies.

Applied Mathematics Series-Mathematical tables, manuals, and studies of special interest to physicists, engineers, chemists, biologists, mathematicians, computer programmers, and others engaged in scientific and technical work.

National Standard Reference Data Series-Provides quantitative data on the physical and chemical properties of materials, compiled from the world's literature and critically evaluated. Developed under a worldwide program coordinated by NBS under the authority of the National Standard Data Act (Public Law 90-396)
NOTE: The principal publication outlet for the foregoing data is the Journal of Physical and Chemical Reference Data (JPCRD) published quarterly for NBS by the American Chemical Society (ACS) and the American Institute of Physics (AIP). Subscriptions, reprints, and supplements available from ACS, 1155 Sixteenth St., NW, Washington, DC 20056.

Building Science Series-Disseminates technical information developed at the Bureau on building materials, components, systems, and whole structures. The series presents research results, test methods, and performance criteria related to the structural and environmental functions and the durability and safety characteristics of building elements and systems.

Technical Notes-Studies or reports which are complete in themselves but restrictive in their treatment of a subject. Analogous to monographs but not so comprehensive in scope or definitive in treatment of the subject area. Often serve as a vehicle for final reports of work performed at NBS under the sponsorship of other government agencies

Voluntary Product Standards-Developed under procedures published by the Department of Commerce in Part 10, Title 15, of the Code of Federal Regulations. The standards establish nationally recognized requirements for products, and provide all concerned interests with a basis for common understanding of the characteristics of the products. NBS administers this program as a supplement to the activities of the private sector standardizing organizations.

Consumer Information Series-Practical information, based on NBS research and experience, covering areas of interest to the consumer. Easily understandable language and illustrations provide useful background knowledge for shopping in today's technological marketplace.

Order the above NBS publications from: Superintendent of Documents, Government Printing Office, Washington, DC 20402.

Order the following NBS publications-FIPS and NBSIR's-from the National Technical Information Services, Springfield, VA 22161.

Federal Information Processing Standards Publications (FIPS PUB)-Publications in this series collectively constitute the Federal Information Processing Standards Register. The Register serves as the official source of information in the Federal Government regarding standards issued by NBS pursuant to the Federal Property and Administrative Services Act of 1949 as amended, Public Law 89-306 (79 Stat. 1127), and as implemented by Executive Order 11717 (38 FR 12315, dated May II, 1973) and Part 6 of Title 15 CFR (Code of Federal Regulations).

NBS Interagency Reports (NBSIR)-A special series of interim or final reports on work performed by NBS for outside sponsors (both government and non-government). In general, initial distribution is handled by the sponsor; public distribution is by the National Technical Information Services, Springfield, VA 22161, in paper copy or microfiche form. 
U.S. DEPARTMENT OF COMMERCE

National Bureau of Standards

Weshington, DC 20234

OFFICIAL BUSINESS

Penalty for Private Use. $\$ 300$
POSTAGE AND FEES PAID U.S. DEPARTMENT OF COMMERCE COM-215

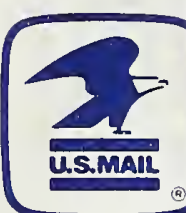

FIRST CLASS 